\title{
Factors the Development of Region Promotion Activities Centre (PKWp) in Lebak District Banten Province
}

\author{
Sierfi Rahayu, Hardi Warsono, Budi Puspo Priyadi \\ Program Studi Magister Ilmu Administrasi, Univeritas Diponegoro, Indonesia \\ Email: sierfirahayu@gmail.com
}

(Received: April 20-2019; revised: March 20-2019; published: May 31-2019)

\begin{abstract}
Lebak Regency as one of the districts that is still lagging behind in Banten Province, does not rule out the possibility of having the potential to be developed so that it can compete with other districts / cities in Banten Province. PKWp is the center of activities that are promoted later to be designated as Regional Activity Centers. There are two sub-districts included in the PKWp in Lebak Regency, namely Maja and Bayah. The problem that occurs is that it still relies on the agricultural sector so that it needs to be developed in the non-agricultural sector, limited supervision of spatial utilization, not yet supporting infrastructure facilities in the development of PKWp, and regional disparities between districts in Lebak Regency. The purpose of this study was to find out and analyze the development of PKWp in Lebak Regency and analyze the driving or inhibiting factors in developing PKWp in Lebak Regency. This study used qualitative research methods. The results of this study the driving factors in regional development, namely physical (education, health, economy and infrastructure) and investment, while inhibiting factors in regional development, namely social, productive population migration, government policies, trade patterns and trade activities.
\end{abstract}

Keywords: Regional development; Promotional; Regional Activity Center.

\section{INTRODUCTION}

Indonesia has committed to the global policy of implementing Sustainable Development Goals (SDGs). The goal of sustainable development is development that maintains an increase in economic welfare, sustainability of social life, environmental quality and guarantees justice and the implementation of governance that is able to maintain an increase in quality of life from one generation to the next (Belletti, Marescotti, \& Touzard, 2017; Farley, 2012; Hilson, Gillani, \& Kutaula, 2018; Howarth, 2007; Langer et al., 2015; Schneider, Kallis, \& Martinez-Alier, 2010; Sodiq et al., 2019). In September 2014 the UN General Assembly in New York stressed that cities must be described more explicitly in global development priorities, supporting a city that is committed to making cities and human settlements inclusive, safe, resilient and sustainable. The state has agreed to the goal that the importance of the problem of scale and space in development practices (Pieterse, Parnell, \& Haysom, 2018). Efforts to achieve TPB / SDGs targets have become national development priorities that require synergy in planning policies at the national and provincial and district / city levels. 
112 Jurnal Ilmiah Ilmu Administrasi Publik: Jurnal Pemikiran dan Penelitian Administrasi Publik Volume 9 Number 1, January - June 2019. Page 111-124

Regional development is a process to direct all the potential of the region concerned to be utilized in an integrated manner to realize community welfare and efforts from the government in alleviating disadvantaged areas. In accordance with Presidential Regulation Number 131/2015 concerning Determination of Disadvantaged Regions in 2015-2019, one of which is Lebak Regency in Banten Province. There are several development indicators that we can pay attention to determine whether the area is lagging or not. One of them can be seen from the Human Development Index (HDI) which explains the condition of the population in terms of education, health and income. Judging from the Human Development Index also Lebak Regency is still the lowest in Banten Province, which is $62.78 \%$ in 2016 while the City of South Tangerang has the highest HDI rate in Banten Province, which is equal to $80.11 \%$ in Banten Province in 2016 (source: BPS Banten Province, 2017). This Human Development Index (HDI) is assessed from 3 (three) aspects, namely: education, health and community income in an area. Based on BPS Banten Province data, shows that the highest percentage of poor people in Banten Province, namely Pandeglang Regency is $9.67 \%$ and Lebak Regency is $8.71 \%$, while for the lowest percentage of poor people in Banten Province, namely South Tangerang City is $1.67 \%$.

One of the efforts to alleviate underdeveloped areas was by developing the region, namely by dividing the territory into PKW, PKWp, PKL. The definition of regional development is a process to direct all the potential of the region concerned to be utilized in an integrated manner to realize people's welfare (Nugraha, 2012). In accordance with the 20142034 RTRW of Lebak Regency, that strategic issues related to the development of the Lebak Regency area include the following matters, one of which is the direction of developing growth centers in Lebak Regency. Growth centers in Lebak Regency in accordance with the direction of the Banten Province RTRW are: 1) Regional Activity Centers (PKW): Rangkasbitung, 2) Promotional Area Activity Centers (PKWp): Bayah, Maja 3) Local Activity Centers (PKL): Malingping. Of the three growth centers in Lebak Regency, researchers will focus on the Promotion Area Activity Center (PKWp). Based on Banten Province Regional Regulation No. 2 of 2011, it is explained that PKWp is a center for activities that are promoted for the future to be designated as Regional Activity Centers (PKW). This is what the researchers consider to focus on PKWp, especially with the existence of two sub-districts involved, namely Bayah and Maja so that later researchers can compare whether or not the same development will be used for the two sub-districts, and what things can be promoted from the two sub-districts and will later be able to become Lebak Regency Regional Activity Center (PKW).

Research from Latuconsina (2017) explains that nationally there are strategic issues in spatial planning, namely: a) The occurrence of conflicts of interest between sectors, such as mining, environment, forestry, regional infrastructure and so on. b) The optimal functioning of spatial planning in order to harmonize, synchronize and integrate the various sector plans and programs. c) The occurrence of irregularities in the use of space from the provisions and norms that should be enforced. The reason is the inconsistency of policies towards spatial planning and weaknesses in development control. d) There is no availability of strict function allocations in the RTRWN. e) There is no openness and sincerity in placing the interests of the sector and region in the framework of spatial planning. f) Lack of ability to refrain from wanting to defend their respective interests excessively. 
The problem of this research in developing at the center of growth, which is still based on the agricultural sector, needs to be developed in the non-agricultural sector, especially for the sub-districts included in the center of the promotion area in Lebak Regency. In addition to the agricultural sector, Bayah and Maja sub-district can be developed but in the non-agricultural sector it also has the opportunity to be developed. In Bayah Subdistrict there is tourism that can be developed and become an industrial area, while for Maja Subdistrict the non-agricultural sector that can be developed, namely the real estate sector or residential area, is supported by a program from the center, namely Kota Baru Maja. Other problems, namely the lack of optimal facilities and infrastructure support in the development of a promotional area activity center. Infrastructure facilities here are not just road infrastructure that gets attention, but such as the development of terminals, railway infrastructure, sea transportation, the development of electricity networks and water resources. In addition, there are also problems that often occur, namely the limited supervision of spatial use so that problems arise such as discrepancies between the potential of the region and the availability of space in the region.

The objectives of regional development are comprehensive and holistic by considering the harmony between various resources as the main elements forming space (natural, artificial, human and activity systems), which are supported by the legal system and institutional systems that surround it (Latuconsina, 2017). According to Rustiadi (2018) "Regions are defined as geographical units with certain specific boundaries where the components of the region interact with each other functionally". So regional boundaries are not always physical and definite but often are dynamic. Regional components include natural biophysical components, artificial resources (infrastructure), humans and institutional forms. According to Nugraha (2012) Regional development is a process to direct all potential areas concerned to be utilized in an integrated manner to realize people's welfare.

According to Lay (1993) indicators that influence regional development are: (1) Physical; Availability of socio-economic facilities such as health facilities, education and economic facilities. (2) Economy; The economic capacity of the population can be seen from the level of family welfare in each region. (3) Social; Population and population quality. According to Williamson (Friedman, 1975). In general some factors are thought to be the cause of an increase in inequality between the regions, namely: (1) productive population migration (working age) and having expertise from less developed regions to areas that have developed. (2) Investments tend to be done in areas that have developed because of market factors where the profits are relatively large. (3) Government policies, tend to result in the concentration of facilities and infrastructure in developing regions. (4) The pattern of trade and trade activities is dominated by industries in developing regions.

According to the National Development Planning Agency (Bappenas, 2006) (Setiyanto \& Irawan, 2016) various regional development concepts that have been implemented include: (a) The concept of regional development based on resource characteristics; (b) The concept of spatial-based regional development; (c) The concept of integrated regional development. This concept emphasizes collaboration between sectors to improve community welfare and poverty reduction in disadvantaged areas. To determine the lagging regions, there are several indicators used. The Ministry of Development of Disadvantaged Areas (2004) uses five indicators as the basis for determining lagging regions in Indonesia, among others : (1) community economy; (2) human resources; (3) financial capability; (4) accessibility; and (5) geographical characteristics. 
114 Jurnal Ilmiah Ilmu Administrasi Publik: Jurnal Pemikiran dan Penelitian Administrasi Publik Volume 9 Number 1, January - June 2019. Page 111-124

(d) The concept of cluster based development. This concept is focused on the interrelationship and dependence between actors in the production network to service, and innovation development efforts. A successful cluster is a cluster that is specialized, has competitiveness and comparative advantage, and is oriented externally. According to Rustiadi, et al (2018) regional development can be considered as a form of positive intervention in development in a region. Therefore, effective strategies are needed for an acceleration in development. Theoretically the strategy for developing new regions can be classified into two categories of strategies, namely: demand side strategy and supply side strategy.

In relation to the development of settlement systems, the RTRWN itself has defined the functions of cities on a national basis based on certain criteria (administrative, economic infrastructure support, and other strategic criteria), namely as National Activity Centers (PKN), Regional Activity Centers (PKW) and Activity Centers Local (street vendor). (Hariyanto \& Tukidi, 2007). The direction of development of growth centers in Lebak Regency is divided into 3 (three), namely: Regional Activity Centers (PKW), Promotional Area Activity Centers (PKWp) and Local Activity Centers (PKL) According to Banten Province Regional Regulation Number 2 of 2011 concerning Banten Province Spatial Planning for 2010-2030, explaining the definition of Promotional Region Activity Centers (PKWp) which are promoted as centers of activity in the future can be designated as PKW (Regional Activity Centers). The strategy for improving the quality of service functions in service centers within the Banten Province area includes one of which is to realize a new promoted regional activity center (PKWp) at regional growth centers as an effort to synergize the national urban service system and provincial development and regional development district / city.

According to Lebak Regency Regional Regulation Number 2 of 2014 concerning Lebak Regency Spatial Planning for 2014-2034, explains the meaning of Promotional Regional Activity Centers (PKWp) is an urban area that serves to serve provincial-scale activities or some districts promoted to later be designated as PKW (Regional Activity Center). PKWp with the main function as a center of activities for trade and service areas, education centers, health centers, urban settlement development centers, tourism centers, and socio-economic service centers. This PKWp is also managed by the Banten Province Regional Development Planning Agency as well as the Regional Activity Center (PKW). This PKWp is one of the centers of growth to reduce inequality in Lebak Regency. Each region has a different term of growth center, such as the research conducted by Sutikno and Maryunani (2007), this study entitled analysis of the potential and competitiveness of the sub-district as the center of growth of Malang District Development Unit (SWP). In this study the term region which is the center of its growth is the Development Area Unit (SWP), then this study also looks more at the analysis of potential and competitiveness.

Based on the background described, the formulation of the problem in this research is what are the driving or inhibiting factors in the development of the Promotion Area Activity Center (PKWp) in Lebak Regency, Banten Province? and the purpose of this study was to analyze the driving or inhibiting factors in the development of the Promotion Area Activity Center (PKWp) in the Lebak Regency of Banten Province. 


\section{METHOD}

This research is based on the type of data collected including in qualitative research (Singarimbun \& Effendi, 1995). According to Creswell \& Creswell (2017) qualitative research is an approach to understanding and deepening the meaning of individuals or groups in social and human problems. This study uses a qualitative descriptive research method. According to Djam'an Satori (2010) work steps to describe an object, phenomenon, or social setting in a narrative writing. This means that data, facts collected in the form of words or images rather than numbers. Describing something means describing what, why, and how the event occurred. The qualitative approach in this study is based on the consideration that the qualitative approach is relevant and fits the research problem. Furthermore, it is used to build understanding and provide explanations of the phenomenon under study.

The main data sources in qualitative research are primary data and secondary data. Primary data sources are data obtained directly from the field and are still raw data. Secondary data sources are data sources obtained from library studies and documentation studies. According to Djam'an Satori (2010) the determination of data sources / informants purposively, which is determined by adjusting to the research objectives or specific objectives. The informants from this study were Banten Provincial Bappeda, Lebak Regency Bappeda, Lebak Regency PUPR Service, economic development in Bayah Subdistrict and Maja Subdistrict, as well as the community. According to Irawan (2006), in a qualitative study which is the most important instrument is the researcher himself. Data collection techniques in this study, namely interviews, observation and documentation study. The data analysis technique used in this study is to use qualitative data analysis techniques following the concepts given by Miles, Huberman, \& Saldaña (2014), namely Data Condensation, Data Display, and Conclusion Drawing / Verifications.

\section{RESULT AND DISCUSSION}

According to Rustiadi, et al (2018) the understanding of the area is very important to note when talking about development programs related to regional development and regional development. In looking at the factors in the development of the Damaged Promotion Area Activities (PKWp) in Lebak Regency, Banten Province is divided into internal and external factors. The internal factor of the researcher looks at the institutional aspect, because this institution is one component in the development of the region. For external factors that influence regional development according to Lay (1993: 53), namely physical and social. According to Williamson (in Friedman and Alonso, 1975: 166), in general some factors are thought to be the cause of an increase in inequality between regions, namely: productive population migration, investment, government policies, trade patterns and trade activities.

The Lebak Regency Government in this case the Office of Public Works and Spatial Planning as an agency that is planning to oversee the development of the region while still coordinating with the Regional Development Planning Agency of Lebak Regency. In this case the researcher looks at the factors that influence the development of the area in the Promotion 
116 Jurnal Ilmiah Ilmu Administrasi Publik: Jurnal Pemikiran dan Penelitian Administrasi Publik Volume 9 Number 1, January - June 2019. Page 111-124

Activity Center conducted by the Public Works and Spatial Planning Service using qualitative data with dimensions of factors that influence the development of the region.

In carrying out the analysis of regional development also see from the supporting or inhibiting factors that can influence in carrying out regional development. Factors supporting or inhibiting the analysis of regional development are used by a theory used to guide the course of this research. The several theoretical dimensions used to determine the supporting or inhibiting factors in this study are seen from institutional, physical, social, productive population migration, investment, government policies, trade patterns and trade activities. The following are the results of the analysis and discussion that the researcher obtained:

\section{Institutional}

Institution in the development of this region can be interpreted as an order and pattern of relations between community members or mutually binding organizations that can determine the form of relations between people or between organizations, accommodated in an organization or network and determined by boundaries and binding norms, rules of ethics formal and informal to control social behavior and incentives to cooperate and achieve common goals. Based on the results of interviews and observations in the field, the researchers found several facts related to internal factors which were obstacles in developing the area in Lebak Regency. In the Lebak District Public Works and Spatial Planning Office, spatial planning is one of the fields in the department so that the spatial planning sector, if seen from the apparatus resources, is still lacking, both in terms of quantity and quality. In accordance with the results of interviews with one of the stakeholders:

"The resources of the spatial apparatus are still lacking in quantity and quality. Quantitatively, there are 10 employees in the spatial sector with details of 5 civil servants and 5 non-civil servants. In quality, it should have an educational background that is planalogically graduated. In these 10 employees only 2 employees are in accordance with education. So that understanding related to spatial planning many do not understand. That is the weakness of the official apparatus resources not yet in accordance with the educational background "(Interview on 11 January 2019).

Position is not in accordance with the educational background. Besides that, every agency should have a spatial planning representative, there is a PWK representative. So that it is more optimal because each department has a different planning program. In terms of supervision due to a lack of apparatus resources, for the control sector when going to the field of one staff from the office and cooperating with the sub-district, namely the PP Satpol. This lack of apparatus resources has an impact on less optimal supervision, according to the results of interviews with one of the stakeholders:

"In terms of supervision due to lack of apparatus resources, for the control sector when going to the field of one staff from the office and cooperating with the sub-district, namely the PP Satpol. Formed a team with regent sk. In a period of 6 months in conducting supervision. To coordinate the PUPR service in collaboration with other agencies that are still related to spatial planning, for example the environmental service, the 
agricultural service. That is one way to deal with a lack of apparatus resources "(Interview on 11 January 2019).

In addition to the lack of apparatus resources, there are other internal problems, namely related to the budget or funding in the development of the region is still not enough. In accordance with the results of interviews with one of the stakeholders regarding factors other than apparatus resources:

"Other constraints other than human resources, namely funding or available budget, because this spatial plan is more needed in the budget for RDTR affairs (Spatial Detail Plan). This RDTR is used as a licensing guide. Only 3 sub-districts in terms of submission, and even then only submission. The Maja RDTR sub-district has not yet been established, and even then it is helped by the center, they are budgeted by the ministry. Not one of the 28 sub-districts in Lebak Regency has an RDTR "(Interview on 11 January 2019).

This can be seen from the availability of the budget for making the RDTR. In Lebak Regency with 28 sub-districts, it does not yet have RDTR, only a few sub-districts have started submission, such as Rangkasbitung and Maja Subdistricts, while the RDTR is actually very supportive in developing the region. The rules also require having an RDTR. The impact that does not have an RDTR, which is in accordance with the results of interviews with one of the stakeholders:

"There is no RDTR, the potential for violations is higher, the licensing basis is from the RDTR not from the RTRW. To enforce compliance with spatial planning. Regarding regional development, there is no RDTR, meaning there are no more micro regional development guidelines "(Interview on 11 January 2019).

However, Lebak Regency is still referring to the RTRW in its spatial planning. The importance of this RDTR as a licensing guide can even be a basis for licensing, this RDTR is also more micro compared to the RTRW so that spatial planning will be more detailed in its area development.

\section{Physical}

Physical here can be the availability of socio-economic facilities such as health facilities, education and economic facilities. Based on the results of interviews and observations in the field, the researchers found that the existing road infrastructure in Kecamatan Bayah and Maja was good because the two sub-districts were assisted by the province and developers or companies. However, there are several regency road sections that are still damaged in Maja District. For educational infrastructure facilities also in the District of Maja and Bayah the availability of schools is relatively good and quite a lot, while the health infrastructure is not good enough. Even though the local government has tried to have sub-district health centers inpatient care but the availability of health equipment is not complete, as there is no radiology, ultrasound devices are also often damaged. Economic facilities are also quite good, such as the availability of markets in each sub-district, but different from their Bayah subdistrict, this is 
118 Jurnal Ilmiah Ilmu Administrasi Publik: Jurnal Pemikiran dan Penelitian Administrasi Publik Volume 9 Number 1, January - June 2019. Page 111-124

actually more shopping in the Pelabuhan Ratu Sukabumi area compared to Rangkasbitung or other areas in Banten Province. The distance and completeness of the shopping center that caused this to happen, but if the problem in the District of Maja is different. Local people are more willing to sell their garden or farm produce to the Jakarta or Tangerang area than they have to sell to Maja or Rangkasbitung markets, with higher selling prices and usually sell out quickly to Jakarta or Tangerang.

The other supporting infrastructure that is not yet available even though it is not optimal is the availability of waste disposal sites where it is very important. This waste disposal site is necessary especially for the District of Maja which in the future will be a densely populated residential area. This must be planned because this is a long-term nature. According to the results of the interview with one of the stakeholders:

"Right now that still doesn't exist and it might be difficult to provide a garbage dump. The difficulty here is due to land acquisition, and consideration of safe distance from settlements. Especially in the future, Maja will have a lot of housing, surely this waste disposal site is very necessary. While we do this garbage disposal to the Citeras area "(Interview on 31 December 2019).

Other infrastructure facilities that have not been optimal such as bus terminals. Bayah Subdistrict even though there is a terminal but it is not yet active, the terminal should also be made in the Sawarna tourist area, besides that another support is the reopening of the Rangkasbitung-Panimbang railroad. This plan has also begun to be realized in 2024, therefore physical factors here are not only related to road infrastructure, but also need to be considered also other supporting infrastructure in optimizing regional development

\section{Social}

This social factor is a factor that influences in socio-cultural changes where it is a change that occurs in social institutions in a society that affects the social system, such as values, social attitudes and behavior patterns among groups in society. Based on the results of interviews and field observations, researchers found some information that the population was very influential in the development of the region because of the projected needs. So the more population, the more projected demand will be. In addition, when the population density is at the middle to low level, the potential is getting higher and easier to develop in the area, it is easier to plan because what is regulated is still small. However, if the population is already crowded, it will be more difficult to develop because there are many things that have to be arranged.

Furthermore, this social factor is not only seen from the population and the quality of the population, but also the socio-cultural factors in the area because indirectly a region will experience socio-cultural changes when the area begins to experience development. As in Bayah because there are already many migrants working in cement factories, the socio-cultural impact of the community has also changed slightly. Culture also influences, for example there is food from outside, chinese food. The level of environmental security is reduced too. Adolescence is feared by the Bayah community with migrants. More extra supervision, a lot of theft occurs. But the positive now is that looking for food for 24 hours is still there, Bayah is 
more crowded. The negativity of living patterns, and all the current expensive things like food, rented, and it is equated with all the prices between migrants and natives, then the consumptive style emerged in the Bayah community. Those are some of the effects of the socio-cultural changes in Bayah District.

\section{Productive population migration}

Productive population migration (working age) and having expertise from less regions develops into developing regions, while the development of this region must be supported by productive and active human resources in participating. Based on observations and the results of interviews that the researchers did, it was found several facts that in the District of Maja and Bayah there were differences in terms of population migration. In Maja Subdistrict this productive population migration is quite a lot, with easy access with a commuter line train that connects Tangerang to Jakarta so that the Maja community has been doing space shuttle work for a long time. Maja is feared by the Regional Government of Lebak Regency to only become a town dormitory. Even though this Maja Subdistrict was included in the program of the 10 Kota Baru centers where this program should have been able to further empower the people of Maja to work in Maja and generate local potential that could support the program.

For the Bayah sub-district, people who migrate due to less work occur. This is because Bayah is not as easy as Maja Sub-District where access to trains has been connected to other more developed regions. This Bayah is still limited by the distance from the city center so that more people in Bayah work in the Bayah area. They further develop local potential such as tourism, even those who work in cement factories are also a little because they prefer a higher salary so they prefer to open places to eat rather than having to work in a cement factory. So the people of Bayah are more likely to take advantage of opportunities that exist in the area rather than having to work outside of Bayah.

\section{Investation}

Investment will tend to be done in areas that have developed due to market factors where the profits are relatively large. In addition to market factors as well, investment will begin to emerge or be interested in investing when the area has potential in the future that will advance and survive in the long term. Based on the results of interviews and field observations that researchers did, that there were facts obtained by researchers where in Maja and Bayah Subdistricts there had been investment from outside, although there were not many, but this investment was long term. Such as the District of Maja and Bayah which became the subdistrict for the growth center in Lebak Regency. In fact, one of the factors why Maja and Bayah is the area of Lebak Regency's growth center is because one of them is investment that is now available and is long-term in nature. At present Maja is in the program of the center as 10 new cities, where there are now several developers or companies that build housing, one of them is Citra Maja Raya, while for Bayah there is now a cement factory investment in PT. Cemindo and SCG even though the new production is PT. Cemindo. In Bayah there is a tourism potential that really deserves to be taken into account, namely Sawarna beach. Based on the results of the interview, it can be seen that: 
120 Jurnal Ilmiah Ilmu Administrasi Publik: Jurnal Pemikiran dan Penelitian Administrasi Publik Volume 9 Number 1, January - June 2019. Page 111-124

"Investments in Maja, can be more quickly developed. Because maja is included in the central program as one of the 10 new cities, so that central intervention will be more in the city. Infrastructure is also fast. Bayah will be more difficult, because it is confined to access. Although there are tourism potentials that can be developed, only a few investors are interested in the shark. The difference in beach tourism in Bayah with Anyer or Carita, the problem is accessibility, because the carita is directly connected to the toll road, so access is easy. But if you have a long time to access it "(Interview on 11 January 2019).

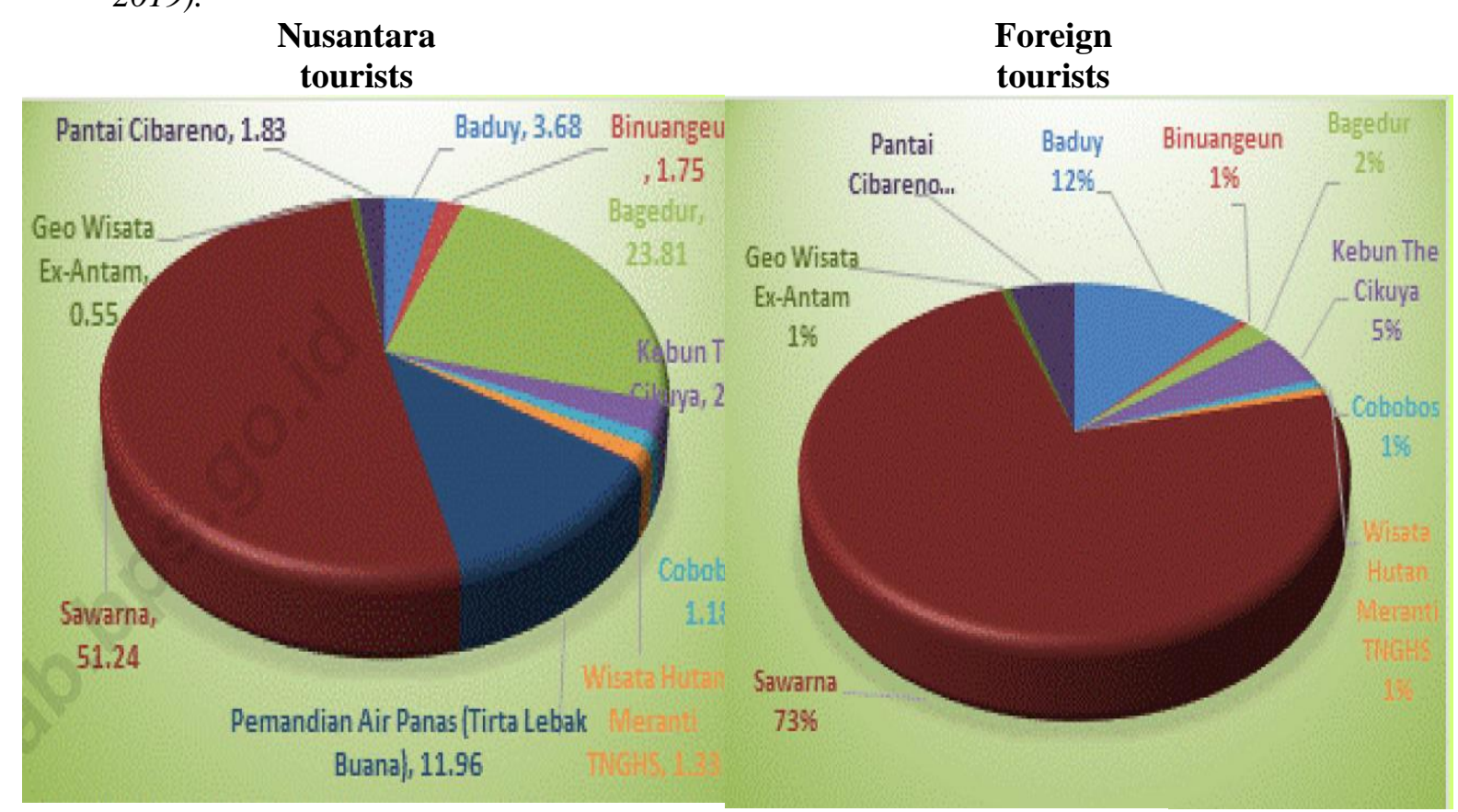

Figure 1 Number of Archipelago and Foreign Tourists in 2017

Source: Regional Statistics of Lebak Regency, 2018

Based on figure 1 shows that the number of tourists both domestic and foreign tourists visit Sawarna Beach the highest at $51.24 \%$ for domestic tourists and $73 \%$ for foreign tourists. It can be seen that Sawarna Beach tourism has the opportunity to be developed and the opportunity for investors is very large. Therefore, even though there are obstacles that are far from the city center, Bayah has investment potential that can be promising in the future.

\section{Government policy}

Government policy is very necessary in carrying out regional development because if it is not in accordance with the applicable regulations, it means that later the development of this region will violate the rules and not be feasible to continue. Based on the results of interviews and field observations, researchers found the fact that in Lebak Regency out of 28 existing subdistricts, none of them had a Spatial Detail Plan (RDTR). Maja already has it even though it is 
still in the process where it is also assisted on a budget basis by the center because Maja entered into the central program as 10 new cities. The Rangkasbitung sub-district as the capital of Lebak Regency does not have one yet, it has not yet arrived at the Regional Regulation. The number of sub-districts that do not have an RDTR is one of the causes is insufficient budgetary factors and also the process is long and needs careful preparation. This RDTR has explained in detail the designation of the area so that with this detailed plan it will further reduce violations in land use. The RDTR is also a guideline in granting permits, but because Lebak Regency does not have RDTR yet, it still uses the RTRW in granting permits and guidelines in spatial planning. Even though this has been regulated in Law Number 16 of 2007 concerning Spatial Planning in article 14 , it is a guideline for spatial planning policies that produce Spatial General Plans and Detailed Spatial Planning in each region. In addition, there is also no clear and good cooperation between provinces because Bayah District is adjacent to Sukabumi Regency, West Java Province. So this government policy should be a driving factor for regional development, but now there are still a number of obstacles in carrying out regional development.

\section{Pattern of trade and trade activities}

The pattern of trade and trade activities is dominated by industries in developing regions. Based on the results of interviews and field observations the researchers found some information that for Bayah and Maja Subdistricts there were not many trade patterns and trade activities in the industrial sector, still dominated by agriculture and plantations. Looking at the long-term future, Maja can develop a home industry because it is adapted to a residential area that will be crowded. This Maja sub-district is not permitted by large industries because Maja is intended for residential areas, while settlements will not be good if they are united with industrial estates. For now, there is only a cement industry, in fact Bayah is actually more agricultural and plantation area compared to industrial estates because industrial estates only exist in 3 villages, namely West Bayah, Pamubulan and Darmasari from a total of 11 villages in Bayah. The work of the majority of the Bayah people is also still a farmer, who turned to the construction workers only a small part because their agricultural land was affected by the construction of a factory where some of them were employed in the factory. In fact there are some people who sell land to the company, the money is bought back agricultural land in other areas so that they still have agricultural land. Unlike in Maja, when their land has been bought by developers or companies, many of them are farmers now, many of whom work as construction workers in housing development projects. It was also the result of a company agreement with the community, that the community was given a ration in recruiting workers so they could work in settlement projects.

\section{CONCLUSION}

Based on the results of the research and discussion it can be concluded that institutionally can be a driving factor and a barrier while the driving factor in the development of this region is physical development and investment. So far, education, health, infrastructure and economic facilities and infrastructure have encouraged regional development, although there are some that have not yet been implemented, such as health and economic facilities. Investment is a driver in 
122 |Jurnal Ilmiah Ilmu Administrasi Publik: Jurnal Pemikiran dan Penelitian Administrasi Publik Volume 9 Number 1, January - June 2019. Page 111-124

regional development because there are long-term investments in Bayah and Maja Subdistricts, while for the following factors are: social problems because of the emergence of a more consumptive and more vulnerable pattern of life in Bayah Subdistrict, productive population migration because there are more migrants in Maja Subdistrict compared to Bayah Subdistrict, government policies due to unclear policies in the division of tasks between the central, provincial and district in developing the region then the RDTR policy already exists but has not been implemented, the pattern of trade and trade activities because in Maja and Bayah Subdistrict trade activities are still dominated by agriculture and plantations but there are opportunities for service sector trade activities in Bayah and Maja Districts.

\section{REFERENCES}

Belletti, G., Marescotti, A., \& Touzard, J.-M. (2017). Geographical Indications, Public Goods, and Sustainable Development: The Roles of Actors' Strategies and Public Policies. World Development, 98, 45-57. https://doi.org/https://doi.org/10.1016/j.worlddev.2015.05.004

Creswell, J. W., \& Creswell, J. D. (2017). Research design: Qualitative, quantitative, and mixed methods approaches. Sage publications.

Djam'an Satori, A. K. (2010). Metode Penelitian Kualitatif. Alfabeta, Bandung.

Farley, J. (2012). Ecosystem services: The economics debate. Ecosystem Services, 1(1), 40-49. https://doi.org/https://doi.org/10.1016/j.ecoser.2012.07.002

Friedman, J. (1975). Regional policy: readings in theory and apllications.

Hilson, G., Gillani, A., \& Kutaula, S. (2018). Towards Sustainable Pro-Poor Development? A Critical Assessment of Fair Trade Gold. Journal of Cleaner Production, 186, 894-904. https://doi.org/https://doi.org/10.1016/j.jclepro.2018.03.123

Howarth, R. B. (2007). Towards an operational sustainability criterion. Ecological Economics, 63(4), 656-663. https://doi.org/https://doi.org/10.1016/j.ecolecon.2007.02.009

Irawan, P. (2006). Metodologi penelitian administrasi. Jakarta: Universitas Terbuka.

Langer, A., Meleis, A., Knaul, F. M., Atun, R., Aran, M., Arreola-Ornelas, H., ... Frenk, J. (2015). Women and Health: the key for sustainable development. The Lancet, 386(9999), 1165-1210. https://doi.org/https://doi.org/10.1016/S0140-6736(15)60497-4

Latuconsina, Z. M. Y. (2017). Analisis Faktor-faktor yang Mempengaruhi Indeks Pembangunan Manusia Kabupaten Malang Berbasis Pendekatan Perwilayahan dan Regresi Panel. Journal of Regional and Rural Development Planning, 1(2), 202-216.

Lay, C. (1993). Ketimpangan dan keterbelakangan di Indonesia. Fakultas Ilmu Sosial dan Ilmu Politik, Universitas Gadjah Mada bekerjasama ....

Miles, M. B., Huberman, A. M., \& Saldaña, J. (2014). Qualitative data analysis: A methods sourcebook. 3rd. Thousand Oaks, CA: Sage. 
Nugraha, A. (2012). Evaluasi Pengembangan Wilayah Dalam Meningkatkan Kawasan Agropolitan Di Kabupaten Tabalong (Studi Wilayah Pembangunan Utara). Jurnal Ilmu Politik \& Pemerintahan Lokal, 1(2).

Pieterse, E., Parnell, S., \& Haysom, G. (2018). African dreams: locating urban infrastructure in the 2030 sustainable developmental agenda. Area Development and Policy, 3(2), 149-169.

Rustiadi, E. (2018). Perencanaan dan pengembangan wilayah. Yayasan Pustaka Obor Indonesia.

Schneider, F., Kallis, G., \& Martinez-Alier, J. (2010). Crisis or opportunity? Economic degrowth for social equity and ecological sustainability. Introduction to this special issue. Journal of Cleaner Production, 18(6), 511-518. https://doi.org/https://doi.org/10.1016/j.jclepro.2010.01.014

Setiyanto, A., \& Irawan, B. (2016). Pembangunan Berbasis Wilayah: Dasar Teori, Konsep Operasional Dan Implementasinya Di Sektor Pertanian. Jakarta: Badan Libang Pertanian.

Singarimbun, M., \& Effendi, S. (1995). Metode Penelitian Survai Edisi Revisi. Jakarta: Lp3ES.

Sodiq, A., Baloch, A. A. B., Khan, S. A., Sezer, N., Mahmoud, S., Jama, M., \& Abdelaal, A. (2019). Towards modern sustainable cities: Review of sustainability principles and trends. Journal of Cleaner Production, 227, 972-1001. https://doi.org/https://doi.org/10.1016/j.jclepro.2019.04.106 
124 Jurnal Ilmiah Ilmu Administrasi Publik: Jurnal Pemikiran dan Penelitian Administrasi Publik Volume 9 Number 1, January - June 2019. Page 111-124 